\title{
Hydrogen-Rich Gas Production from Steam Gasification of Bio-char in the Presence of $\mathrm{CaO}$
}

 \\ Nathalie Lyczko $^{1} \cdot$ Yuanjun Tang $^{2} \cdot$ Marion Ducousso ${ }^{1}$
}

\begin{abstract}
The steam gasification of bio-char to produce hydrogen-rich gas with $\mathrm{CaO}$ as in-bed catalyst is experimentally investigated in a fluidized bed reactor. The purpose of the study is twofold: (1) evaluate the optimal operating conditions of catalytic gasification for hydrogenrich gas production, by examining catalyst activity and steam flowrate; (2) optimize the process by investigating the potential for reducing the gasification temperature. Results reveal that increasing the $\mathrm{CaO} /$ wood mass ratio from 0 to 1.0 is effective for both $\mathrm{H}_{2}$ improvement and tar reduction; this is attributed to enhanced $\mathrm{CO}_{2}$ absorption and reforming reactions. Increasing the steam flowrate is beneficial towards $\mathrm{H}_{2}$ production via the water gas shift reactions. A maximum $\mathrm{H}_{2}$ concentration is achieved at a steam flowrate of $160 \mathrm{~g} / \mathrm{h}$; however, excessive steam injection will lead to an opposite effect, due to decreased available heat. The reaction temperature should be balanced between the gasification performance and $\mathrm{CaO}$ carbonation ability, and the optimal temperature is found to be $700{ }^{\circ} \mathrm{C}$ in this study. Comparing the results with non-catalytic high-temperature gasification, $50 \% \mathrm{CaO}$ addition at $700{ }^{\circ} \mathrm{C}$ could reach as high $\mathrm{H}_{2}$ yield as that gasified at $800{ }^{\circ} \mathrm{C}$ without catalyst. Meanwhile, the use of $\mathrm{CaO}$ also optimizes the gasification performance with a much higher $\mathrm{H}_{2}$ concentration, a higher $\mathrm{H}_{2} / \mathrm{CO}$ ratio and reduced tar yield. Therefore, it is concluded that $50 \% \mathrm{CaO}$ addition as
\end{abstract}

Yong Chi

chiyong@zju.edu.cn

1 Centre RAPSODEE, Ecole des Mines Albi, Campus Jarlard, 81013 Albi Cedex, France

2 State Key Laboratory of Clean Energy Utilization, Zhejiang University, Hangzhou, China catalyst at $700{ }^{\circ} \mathrm{C}$ is effective to reduce the steam gasification reaction temperature by $14 \%$ (ca. $100{ }^{\circ} \mathrm{C}$ ).

Keywords Calcium oxide - Steam gasification of biochar $\cdot \mathrm{CO}_{2}$ absorption $\cdot$ Hydrogen production $\cdot$ Fluidized bed

\section{Introduction}

With increasing demand of energy and the environmental impact from fossil fuel use, energy recovery from waste biomass such as forestry residue and agricultural waste is gaining increasing attentions. Thermal treatment is the most common conversion method to upgrade biomass energy quality [1], among which pyrolysis is regarded as an economical and promising process to obtain high energy efficiency and low emissions [2]. By pyrolysis, biomass is converted into bio-oil, bio-char and gaseous fraction. In this regard, gaseous and liquid products are suitable to be used as fuels for feeding efficient energy generation devices, or as chemicals. On the other hand, bio-char could also achieve utilization rather than being disposed of, such as burned for energy recovery [3], prepared as activated carbon [4], or used in soil amendment [5].

Recently, gasification of bio-char for hydrogen-rich gas production has gained increasing interest as a potential energy utilization route of the bio-char. With steam introduced as gasification agent, bio-char exhibits effective ability to produce syngas with a high hydrogen content, which is regarded as a clean, low carbon future source of energy. Compared with raw biomass or wastes, the char produced from pyrolysis significantly exhibits a reduced volatile and oxygen content; in which fixed carbon content is largely accumulated [6]. Such property makes char 
highly reactive towards steam gasification. Thus $\mathrm{H}_{2}$-rich gas can be obtained by adjusting the steam to char ratio [7], offering possibilities for a higher $\mathrm{H}_{2} / \mathrm{CO}$ ratio to satisfy its further utilization [8].

Calcium oxide $(\mathrm{CaO})$ has been widely used as an in-bed catalyst in biomass gasification, thanks to its low cost and abundant availability, in order to further improve hydrogen production from syngas $[9,10]$. The loaded $\mathrm{CaO}$ to the gasifier takes effect via several pathways. Firstly, $\mathrm{CaO}$ acts as a sorbent for $\mathrm{CO}_{2}$ absorption to form $\mathrm{CaCO}_{3}$. Following the decrease in $\mathrm{CO}_{2}$ partial pressure, the water gas shift reaction is enhanced towards hydrogen production. Secondly, since the $\mathrm{CaO}$ carbonation reaction is exothermic, the releasing heat could also provide necessary energy to facilitate the endothermic gasification process [11].

Tar formation is a major issue concerning biomass gasification since it may decrease the system efficiency and even block and damage downstream gasifier equipment [12]. Another potential advantage of the $\mathrm{CaO}$ additives is the possibility to reduce tar. As it has been reported [13], $\mathrm{CaO}$ could catalytically contribute to tar cracking and accelerate the reaction between tar and $\mathrm{H}_{2} \mathrm{O}$, therefore it significantly reduces the tar content of the product gas from a gasifier.

Considering the catalytic effect of $\mathrm{CaO}$ on gasification, it is thus proposed that in situ $\mathrm{CaO}$ additive could serve as an efficient approach to reduce the steam gasification temperature compared with the non-catalytic process. Actually, the current steam gasification is mostly carried out at a relatively high temperature above $1000{ }^{\circ} \mathrm{C}$ to ensure the gasification performance [14]. Such high reaction temperature leads to a lower energy efficiency and poor economy. On the other hand, due to the ability on $\mathrm{H}_{2}$ enhancement and tar reduction, the $\mathrm{CaO}$ catalytic gasification offers the possibility to obtain as high quality as the syngas produced by non-catalytic gasification, thus substantially lowers the required gasification temperature. Ohtsuka [15] studied the reactivity of coal by steam gasification, indicating that the reaction temperature could be decreased by $110-150{ }^{\circ} \mathrm{C}$ in the presence of $\mathrm{Ca}(\mathrm{OH})_{2}$. This value was obtained at ca. $150{ }^{\circ} \mathrm{C}$ by the study of Dalai et al [16], when using $\mathrm{CaO}$ as catalyst on biomass steam gasification. However in the field of bio-char catalytic steam gasification, study on the reaction temperature reduction potential is still limited; therefore conducting such an assessment is significantly meaningful.

Therefore, steam gasification of bio-char in a fluidized bed reactor has been investigated in this study, using $\mathrm{CaO}$ as in-bed catalyst. The purpose of the study is twofolds: (1) to evaluate the optimal working condition of catalytic gasification for hydrogen-rich gas production; (2) investigate the potential of reducing the gasification temperature by using catalyst. The influence of $\mathrm{CaO}$ catalyst activity, steam flowrate and reaction temperature is studied. The knowledge acquired would assist in the industrial application bio-char gasification technique and develop a more effective and economical steam gasification process in converting biomass to energy.

\section{Materials and Methods}

\section{Samples and Catalyst}

Poplar wood chip, which is one of the most representative types of biomass, is used as the feedstock in this study. It is produced by grounding the raw poplar wood into sizes of ca. $4 \mathrm{~mm} \times 4 \mathrm{~mm} \times 1 \mathrm{~mm}$. This results in a relatively homogeneous starting material for experiments. The proximate and ultimate analysis of the wood are shown in Table 1. Compared with other commonly used biomass such as corn stover or switchgrass, poplar wood has a high calorific value $(17.87 \mathrm{MJ} / \mathrm{kg}$, lower heating value, LHV) and a low sulfur content ( $0.64 \%$ of dried wt) [17]. Calcium oxide $(\mathrm{CaO})$ is adopted as in-bed catalyst, which is purchased according to the Chinese national standard "GB/T 15897-1995" with 99\% purity. The $\mathrm{CaO}$ reagent is sieved beforehand and a same fraction of $0.28-0.45 \mathrm{~mm}$ is used. Its specific surface area is $2.38 \mathrm{~m}^{2} / \mathrm{g}$, as measured in an ASAP 2010 apparatus.

\section{Experimental Apparatus and Procedures}

Gasification experiments are performed in a laboratory batch-scale fluidized bed reactor. Schematic diagram of the apparatus is depicted in Fig. 1. The furnace is made of stainless steel, with the main reaction chamber $600 \mathrm{~mm}$ in height and $60 \mathrm{~mm}$ in inner diameter [18]. Ten thermocouples are employed to monitor the temperature profile throughout the reactor in the vertical direction. The reactor is heated externally up to $1200{ }^{\circ} \mathrm{C}$; and the temperature is controlled by a thermocouple placed close to the middle of the reactor. Two frits are equipped on the bottom and top of the furnace, respectively. The bottom one is to hold the feedstock; while the top one is to prevent char escaping from the reactor. Steam acts as the gasifying agent, which is provided by steam generator from the bottom of the furnace at controlled flowrate. To prevent tar condensing from the flue gas, a heating tape is installed in outlet pipe to maintain the temperature above $200{ }^{\circ} \mathrm{C}$.

The experimental procedures are divided into two steps: bio-char production and steam gasification, which is consecutive throughout the whole reaction. At the beginning of each test, a total of $80 \mathrm{~g}$ poplar wood chip is mixed with $\mathrm{CaO}$ catalyst at specified mass ratios and put into the furnace. Afterwards the furnace is heated to the desired 
Table 1 Proximate and ultimate analysis of poplar wood and its pyrolytic bio-char

Fig. 1 Schematic diagram of the furnace. 1 reaction chamber; 2 thermocouples; 3 steam generator; 4 controller; 5 outlet pipe with heating tape; 6 absorption solution with water; 7 empty impinger; 8 ice-water bath

\begin{tabular}{|c|c|c|c|c|c|c|c|c|c|c|}
\hline & \multicolumn{4}{|c|}{ Proximate analysis (ad, wt\%) } & \multicolumn{5}{|c|}{ Ultimate analysis (ad, wt\%) } & \multirow[t]{2}{*}{ LHV (MJ/kg) } \\
\hline & $\mathrm{M}^{\mathrm{b}}$ & $\mathrm{V}^{\mathrm{b}}$ & $\mathrm{FC}^{\mathrm{b}}$ & $\mathrm{A}^{\mathrm{b}}$ & $\mathrm{C}$ & $\mathrm{H}$ & $\mathrm{O}$ & $\mathrm{N}$ & $S$ & \\
\hline Poplar wood & 9.87 & 77.03 & 12.57 & 0.53 & 44.41 & 5.07 & 39.36 & 0.12 & 0.64 & 17.87 \\
\hline Wood char ${ }^{\mathrm{a}}$ & 6.33 & 10.84 & 80.42 & 2.41 & 79.23 & 2.77 & 9.02 & 0.24 & 0 & 30.52 \\
\hline
\end{tabular}

${ }^{a}$ Wood bio-char is produced through pyrolysis in $\mathrm{N}_{2}$ atmosphere to a temperature of $700{ }^{\circ} \mathrm{C}$ at a constant heating rate of $20{ }^{\circ} \mathrm{C} / \mathrm{min}$

${ }^{\mathrm{b}}$ For proximate analysis, M, V, FC and A represents moisture, volatiles, fixed carbon and ash, respectively

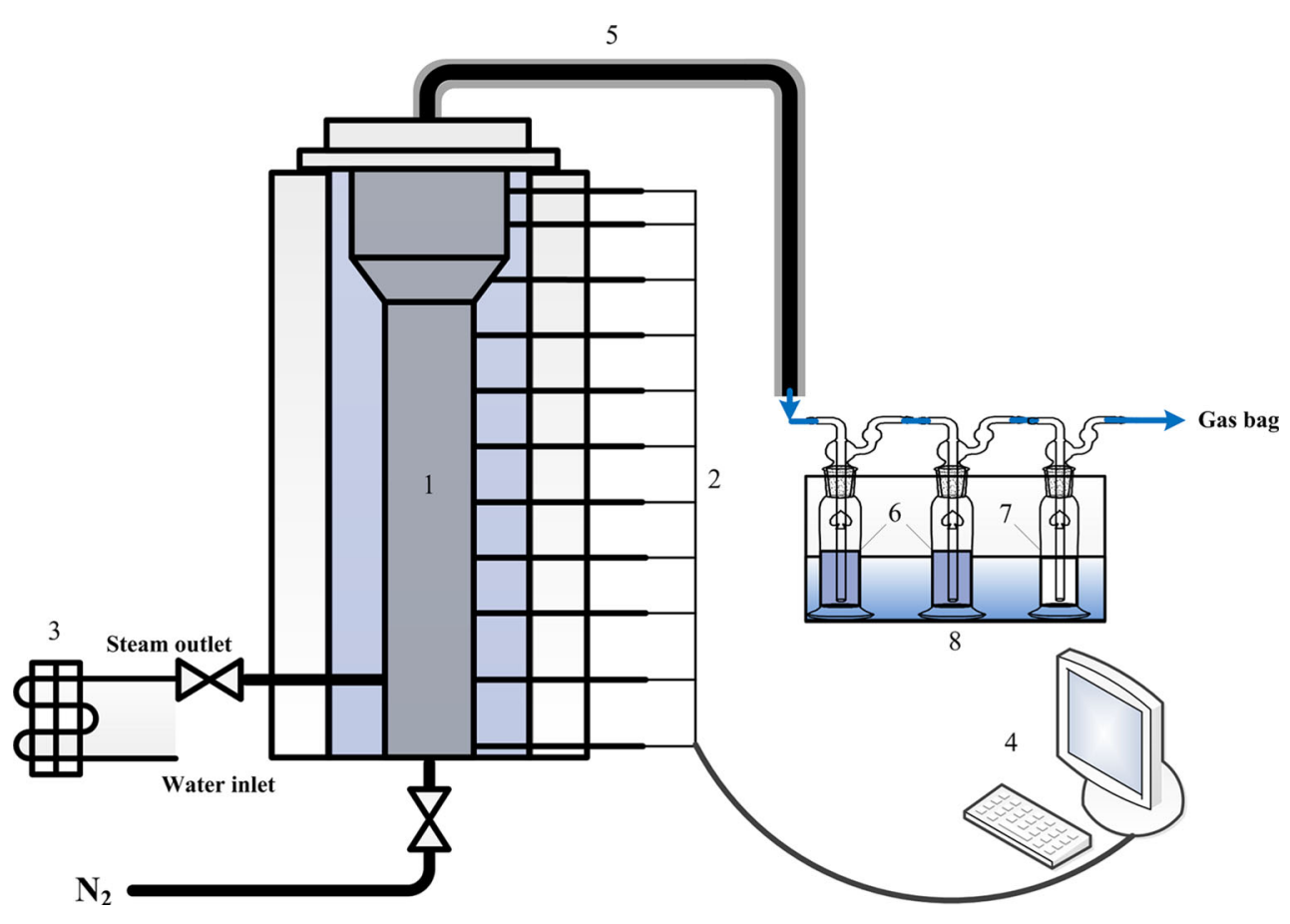

temperature at a constant heating rate of $20^{\circ} \mathrm{C} / \mathrm{min}$. Nitrogen is introduced as the purge gas at a steady flowrate of $0.6 \mathrm{Nm}^{3} / \mathrm{h}$. Therefore the bio-char is actually produced under pyrolysis condition. The properties of the obtained bio-char (at $700{ }^{\circ} \mathrm{C}$ ) are shown in Table 1 . It could be found that compared with the raw poplar wood, the volatile matter of the bio-char is decreased to a large extent, accompanied by a significantly increased ratio of fixed carbon content. This effectively results in an increased energy density of the material, i.e., the LHV of the bio-char is increased from 17.87 to $30.52 \mathrm{MJ} / \mathrm{kg}$. And the yield of bio-char at this reaction temperature is $0.24 \mathrm{~g} / \mathrm{g}$-wood. Once the desired temperature is reached, steam is injected to react with the pyrolytic bio-char. From this point the steam gasification step starts, and the product gas begins to be collected by gas sampling bag. The raw flue gas passes through a series of three impingers immersed in an icewater bath for tar removal and excess steam condensation. The first and second bottles are filled with water; and the third one is empty for moisture removal. The gasification is maintained for a period of $15 \mathrm{~min}$. After that, the steam and the electrical heater are turned off but $\mathrm{N}_{2}$ is still supplied until the furnace reaching room temperature.

The effect of steam $\mathrm{CaO}$ additive, flowrate and temperature on gasification characteristics is investigated. The amount of $\mathrm{CaO}$ additive loaded is $0,16,40$ and $80 \mathrm{~g}$, corresponding to the $\mathrm{CaO} /$ wood mass ratio of $0,0.2,0.5$ and 1. Steam flowrate varies from 80 to $320 \mathrm{~g} / \mathrm{h}$, and a temperature series of $600,650,700,750$ and $800{ }^{\circ} \mathrm{C}$ is examined. In order to verify the potential effect of $\mathrm{CaO}$ on reducing the gasification operating temperature, non-catalyst high-temperature steam gasification at 800 and $900{ }^{\circ} \mathrm{C}$ is carried out as comparison. For each trial, critical mass balance calculation is conducted to ensure the reliability of test data.

\section{Methods of Sampling and Analysis}

Syngas components including $\mathrm{H}_{2}, \mathrm{CO}, \mathrm{CO}_{2}, \mathrm{CH}_{4}$ and $\mathrm{N}_{2}$ are measured. The gas sampling is analyzed using gas chromatography (micro GC-3000A analyzer, Agilent). The total gas yield $\left(\mathrm{Nm}^{3} / \mathrm{kg}\right.$-wood) is quantified according to 
$\mathrm{N}_{2}$ balance, based on the known $\mathrm{N}_{2}$ flowrate and the molar ratio of $\mathrm{N}_{2}$ in the produced gas [13]. The liquid in the impingers are extracted by dichloromethane solution and separated into organic and inorganic fractions. The organic part is then heated for dichloromethane evaporation and the remaining fraction is recorded as the tar yield [19, 20]. The produced solid residue is collected from the bottom of the furnace and weighted. X-ray diffraction (XRD) measurements of the solid product are carried out to determine main components and investigate the catalytic performance of the experiment.

\section{Results and Discussion}

According to the aim of the study, this section is divided into two parts. "Effect of Operating Conditions on Catalytic Steam Gasification" section investigates the effect of operating conditions on the performance of catalytic steam gasification, where the catalyst activity and steam flowrate is examined. Based on the results obtained, "Catalytic Steam Gasification Process Optimization" section mainly focuses on process optimization. Catalytic steam gasification under different temperatures is conducted, and the results are further compared with non-catalyst gasification cases to verify the potential of reducing the gasification temperature.

\section{Effect of Operating Conditions on Catalytic Steam Gasification}

\section{Catalyst Activity}

The first operating conditions investigated are focused on the effect of catalyst loading. Figure 2 illustrates the effect of $\mathrm{CaO} /$ wood mass ratio (as $\mathrm{x}$ axis) as a function of the gas composition and $\mathrm{H}_{2}$ yield (as y axis), respectively; which is studied at steam flowrate of $160 \mathrm{~g} / \mathrm{h}$ and temperature of $700{ }^{\circ} \mathrm{C}$. The $\mathrm{CaO} /$ wood mass ratio studied ranges from 0 to 1 , which actually corresponds to $\mathrm{CaO} /$ char mass ratio at 0 , $0.84,2.11$ and 4.21 , as illustrated by another $\mathrm{x}$ axis in Fig. 2. Results from Fig. 2 show that the $\mathrm{H}_{2}$ yield is increased rapidly from $0.06 \mathrm{Nm}^{3} / \mathrm{kg}$ of wood in the absence of $\mathrm{CaO}$ to $0.12 \mathrm{Nm}^{3} / \mathrm{kg}$ of wood at $\mathrm{CaO} /$ wood mass ratio of 1.0. It could be also noticed that the $\mathrm{H}_{2}$ yield is increased quite linearly with the increase of the ratio up to 0.5 . At the same time, the $\mathrm{H}_{2}$ concentration is elevated to $64.2 \%$, following a linear trend. The results indicate that $\mathrm{CaO}$ catalyst enhances the $\mathrm{H}_{2}$ production (volume produced) and increases the quality of the syngas (higher $\mathrm{H}_{2}$ concentration in the gas), as expected.

It has been proven that during steam gasification process, the final gas composition is a result of several complex and competing reactions. The important reactions involved in steam gasification are listed as follows, considering the actual elemental composition of the bio-char according to Table 1.

Stoichiometric steam reforming reaction:

$\mathrm{C}_{6.60} \mathrm{H}_{2.77} \mathrm{O}_{0.56}+6.04 \mathrm{H}_{2} \mathrm{O} \leftrightarrow 6.60 \mathrm{CO}+7.425 \mathrm{H}_{2}$

Water gas reaction:

$\mathrm{C}+\mathrm{H}_{2} \mathrm{O} \leftrightarrow \mathrm{CO}+\mathrm{H}_{2}-131 \mathrm{~kJ} / \mathrm{mol}$

Water gas shift reaction:

$\mathrm{CO}+\mathrm{H}_{2} \mathrm{O} \leftrightarrow \mathrm{CO}_{2}+\mathrm{H}_{2}+41 \mathrm{~kJ} / \mathrm{mol}$

Boudouard reaction:

$\mathrm{C}+\mathrm{CO}_{2} \leftrightarrow 2 \mathrm{CO}-162.4 \mathrm{~kJ} / \mathrm{mol}$

Tar reforming reaction:

$\mathrm{Tar}+\mathrm{H}_{2} \mathrm{O} \stackrel{\mathrm{CaO}}{\longrightarrow} \mathrm{H}_{2}+\mathrm{CO}_{2}+\mathrm{CO}+$ hydrocarbon $+\cdots$

According to the stoichiometric reaction from Eq. 1, a complete steam gasification of the bio-char should result in a high amount of $\mathrm{CO}$ and $\mathrm{H}_{2}$, and $\mathrm{a}_{2} / \mathrm{CO}$ ratio of 1.125 . Figure 2 verifies that the high $\mathrm{H}_{2}$ concentration reaches $43.6 \%$ without catalyst. Nevertheless the $\mathrm{CO}$ concentration is quite low, representing one third of $\mathrm{CO}_{2}$ value. This is mainly attributed to the water gas shift reaction (Eq. 3). In the presence of excessive water during steam gasification, $\mathrm{CO}_{2}$ could be produced in higher amount as a result of $\mathrm{CO}$ oxidation. Meanwhile, Fig. 2 shows also that with the increasing $\mathrm{CaO}$ loading, the increase in $\mathrm{H}_{2}$ concentration is accompanied with a significant decrease in $\mathrm{CO}_{2}$ concentration. This decrease is also quite linear, indicating that the $\mathrm{CaO}$ concentration is involved in the amount of $\mathrm{CO}_{2}$ measured in the gas phase.

To better verify the catalytic mechanism, $\mathrm{CO}_{2}$ equilibrium is conducted. According to the involved reactions, the production of $\mathrm{CO}_{2}$ could be attributed to the water gas shift reaction (Eq. 3) and tar reforming reaction (Eq. 5); while Boudouard reaction (Eq. 4) is the main contributor to $\mathrm{CO}_{2}$ consumption. The mechanism of $\mathrm{CO}_{2}$ absorption by $\mathrm{CaO}$ is via carbonation reaction Eq. 6, which could further lower the $\mathrm{CO}_{2}$ partial pressure and enhance the water gas shift reaction to produce more $\mathrm{H}_{2}$ [9]. Previous studies have indicated that the catalytic effect of $\mathrm{CaO}$ is via two sides: to serve as $\mathrm{CO}_{2}$ acceptor, as well as to participate in the tar reforming reactions [21]. From results in Fig. 2, the concentration of $\mathrm{CO}$ and $\mathrm{CH}_{4}$ exhibits an increasing trend at higher $\mathrm{CaO} /$ wood ratios, which could be attributed to the facilitated tar reforming reaction. Nevertheless, the changed tendency is not as obvious as the linearly decreased $\mathrm{CO}_{2}$ concentration. Thus, it could be speculated that the dominant catalytic mechanism of $\mathrm{CaO}$ at the reaction 
Fig. 2 Effect of $\mathrm{CaO} /$ wood syngas composition (steam flowrate $=160 \mathrm{~g} / \mathrm{h}$; temperature $\left.=700{ }^{\circ} \mathrm{C}\right) . *$ Note $\mathrm{CaO} /$ wood $=0$ stands for noncatalyst gasification case mass ratio on $\mathrm{H}_{2}$ production and
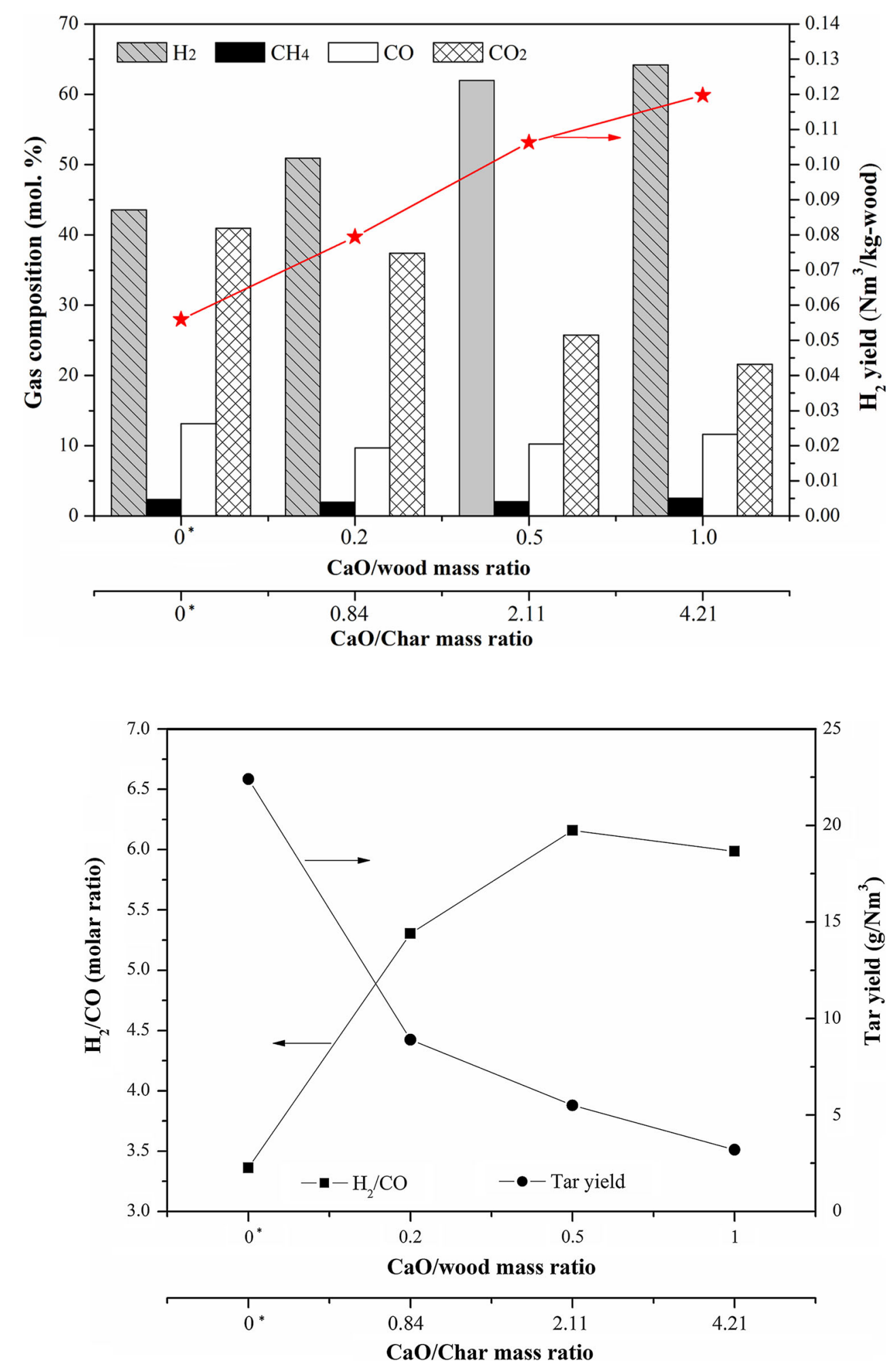

Fig. 3 Effect of $\mathrm{CaO} /$ wood ratio on syngas and tar yield (steam flowrate $=160 \mathrm{~g} / \mathrm{h}$; temperature $\left.=700{ }^{\circ} \mathrm{C}\right) . *$ Note $\mathrm{CaO} /$ wood $=0$ stands for noncatalyst gasification case

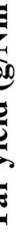

conditions is via $\mathrm{CO}_{2}$ absorption, mainly due to that the contact frequency between $\mathrm{CO}_{2}$ gas and $\mathrm{CaO}$ sorbents is improved with the increasing $\mathrm{CaO}$ amount, and in the fluidized bed.Carbonation reaction

$\mathrm{CaO}+\mathrm{CO}_{2} \rightarrow \mathrm{CaCO}_{3}+178 \mathrm{~kJ} / \mathrm{mol}$
The gasification performance under different $\mathrm{CaO}$ /wood mass ratios is presented in Fig. 3. Increasing the $\mathrm{CaO}$ ratio, the $\mathrm{H}_{2} / \mathrm{CO}$ shows an increasing trend from 3.36 to 5.99. The peak value of 6.16 appears at $\mathrm{CaO} /$ wood mass ratio of 0.5 ; thereafter the $\mathrm{H}_{2} / \mathrm{CO}$ ratio exhibits a slight decrease 
since the increase in $\mathrm{H}_{2}$ production is not as obvious as $\mathrm{CO}$. This is companied by the decline in the tar yield from 22.4 to $3.2 \mathrm{~g} / \mathrm{Nm}^{3}$. Especially, the concentration of tar could be effectively reduced by $60 \%$ under $\mathrm{CaO} /$ wood ratio of 0.2 compared with that in the absence of $\mathrm{CaO}$. It is also observed that the color of the collected tars turns from deep brown into light yellow when increasing $\mathrm{CaO} /$ wood ratio from 0 to 1 , indicating that the tar reforming reaction (Eq. 5) is indeed enhanced by $\mathrm{CaO}$ catalyst. Research by Han $[11,22]$ proved that $\mathrm{CaO}$ could catalyze the reduction reactions of tar species such as toluene, phenol and formic acid. Besides, recent studies also reported that the $\mathrm{O}^{2-}$ ions formed as the active sites on $\mathrm{CaO}$ could disrupt the stability of the $\pi$-electron cloud of tar species and finally leads to the splitting of the aromatic rings [14, 23]. For practical application, it is evident that the tar content should be down to a lower level to avoid the damage the downstream energy conversion device. Elimination of tar inside the gasifier seems to be an optimal method, since removing the tar from the syngas by means of a wet physical method owes the drawback of losing the chemical energy [24]. In this sense, using $\mathrm{CaO}$ as catalyst could be served as a potential approach for both $\mathrm{H}_{2}$-rich and tar-free gas production.

\section{Influence of Steam Flowrate}

Figure 4 presents the influence of steam flowrate on $\mathrm{H}_{2}$ production and syngas composition at $\mathrm{CaO} /$ wood of 0.2 and $700{ }^{\circ} \mathrm{C}$, using the varied steam flowrate of 80-320 g/h (equal to $1.05-4.21 \mathrm{~g} / \mathrm{g}$-char) as $\mathrm{x}$ axis and the gas composition and $\mathrm{H}_{2}$ yield as $\mathrm{y}$ axis, respectively. Under such test conditions, the speed of steam is in a range of $0.09-0.20 \mathrm{~m} / \mathrm{s}$. Results indicate that with the initial increase in steam flowrate from 80 to $160 \mathrm{~g} / \mathrm{h}$, the $\mathrm{H}_{2}$ yield is remarkably increased from 0.059 to $0.079 \mathrm{Nm}^{3} / \mathrm{kg}$ of wood. However the $\mathrm{H}_{2}$ yield will drop to 0.063 and 0.047 $\mathrm{Nm}^{3} / \mathrm{kg}$ of wood when further increase the steam flowrate to 240 and $320 \mathrm{~g} / \mathrm{h}$, respectively; corresponding to a decreased rate of 20 and $41 \%$. In regard to the syngas composition, the $\mathrm{H}_{2}$ concentration exhibits a similar trend of first increase and then decrease; the maximum $\mathrm{H}_{2}$ content reaches $50.9 \%$ as steam flowrate is $160 \mathrm{~g} / \mathrm{h}$. The evolution of $\mathrm{CH}_{4}$ is opposite although in a relatively low concentration.

The increased steam quality could effectively enhance the concentration of steam in reactor to facilitate steam reforming reactions (Eqs. 1-3), which improves the $\mathrm{H}_{2}$ yield and concentration in the syngas. It could be verified by the decreased concentration of $\mathrm{CH}_{4}$. It is also suggested that $\mathrm{CaO}$ reveals better catalytic performance at the adequate presence of steam. Manovic et al. [25] concluded that steam hydration would efficiently promote the carbonation reactivity of $\mathrm{CaO}$, which is helpful to further shift the thermodynamic equilibriums of water gas (Eq. 2) and water gas shift (Eq. 3) reactions towards the formation of $\mathrm{H}_{2}$. Nevertheless when the steam flowrate further exceeds $160 \mathrm{~g} / \mathrm{h}$, a declined trend of $\mathrm{H}_{2}$ yield and concentration is
Fig. 4 Effect of steam flowrate on $\mathrm{H}_{2}$ production and syngas composition $(\mathrm{CaO} /$ wood $=0.2$; temperature $=700{ }^{\circ} \mathrm{C}$ )

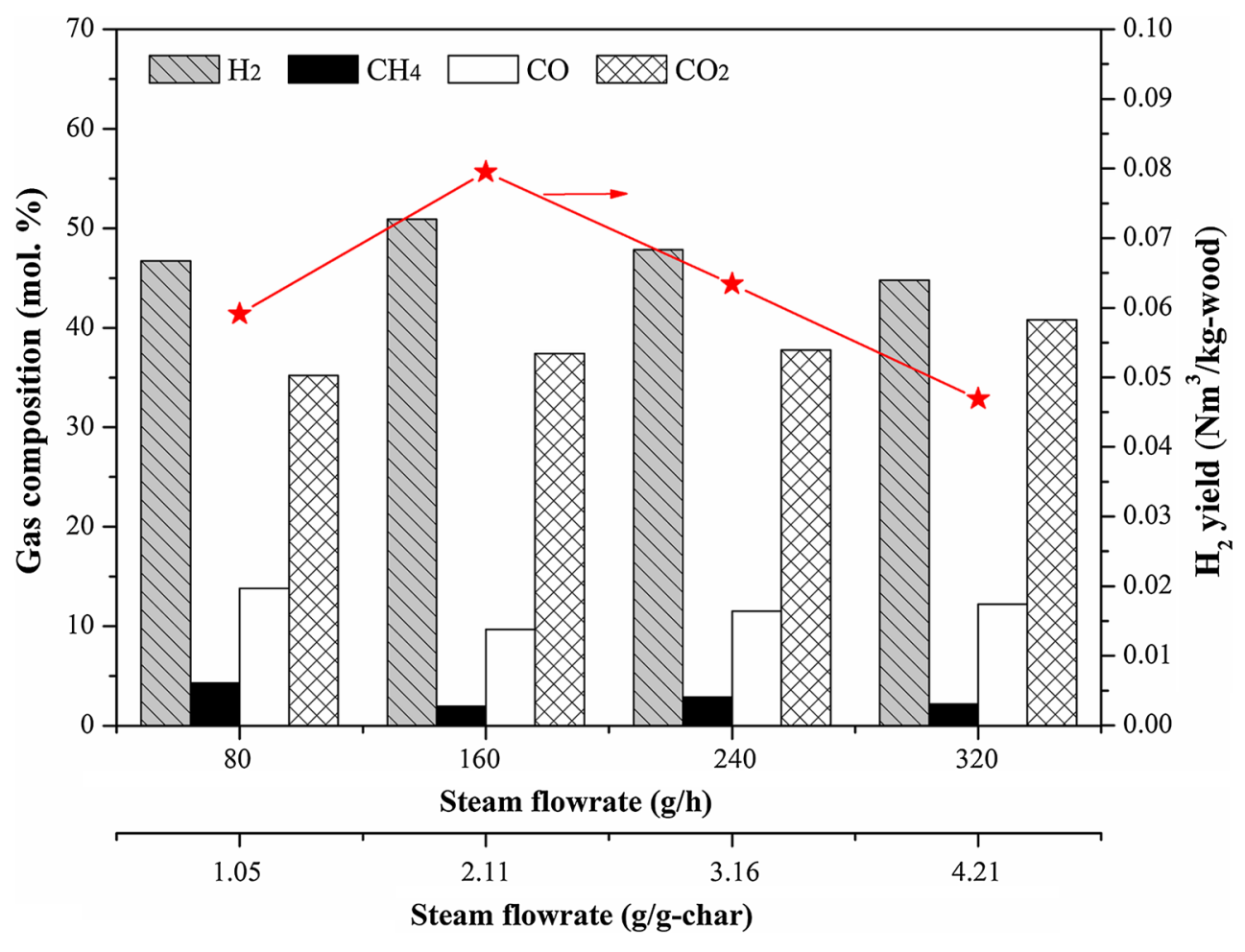


obtained. Acharya et al. [9] and Li et al. [26] also observed a decreased $\mathrm{H}_{2}$ production at higher steam flowrates $\left(\mathrm{H}_{2} \mathrm{O} /\right.$ MSW mass ratio of $1.33-2.66$ and $\mathrm{H}_{2} \mathrm{O} / \mathrm{C}$ mass ratio of $0.83-1.58$ in their studies, respectively). This phenomenon could probably due to that at higher steam flowrate, the amount of steam is sufficient inside the furnace and is no longer the rate limiting step. Then the further increase in steam flowrate would not facilitate the reaction; on the contrary this will result in the decreased available heat in the reactor by the absorption of excessive steam.

The products characteristics as a function of steam flowrate are shown in Table 2. The product distribution of syngas, tar and char exceeds $100 \%$ due to the reaction of steam. With steam flowrate increasing from 80 to $320 \mathrm{~g} / \mathrm{h}$, the char yield decreases gradually from 86.7 to $85.4 \%$, which is explained by Paviet [27] that a higher steam molar fraction has resulted in a lower diffusion resistance of the bio-char. However, the production of char turns to have a slightly rise when further increase the steam flowrate to 240 and $320 \mathrm{~g} / \mathrm{h}$, since the primary decomposition of char is inhibited at a lower reaction temperature. Similarly, the tar concentration reaches its minimum of $8.9 \mathrm{~g} / \mathrm{Nm}^{3}$ at steam flowrate of $160 \mathrm{~g} / \mathrm{h}$; and then slightly increases to $9.6 \mathrm{~g} / \mathrm{Nm}^{3}$.

The $\mathrm{H}_{2} / \mathrm{CO}$ molar ratio shows an increasing trend, in agreement with the results of $\mathrm{He}$ [28]. It could be attributed to the gradually decreased $\mathrm{CO}$ concentration as well as the increased $\mathrm{H}_{2}$ content at lower steam flowrate. As a consequence, the maximum $\mathrm{H}_{2} / \mathrm{CO}$ value of 5.30 appears under steam flowrate of $160 \mathrm{~g} / \mathrm{h}$. Previous researches have concluded that syngas with different levels of $\mathrm{H}_{2} / \mathrm{CO}$ ratio are suitable for different applications. The high range of $\mathrm{H}_{2} / \mathrm{CO}$ ratio could open application for syngas in chemical industry, for ammonia synthesis or for fuel cell applications [29].

\section{Catalytic Steam Gasification Process Optimization}

Based on the results obtained, the next step of using $\mathrm{CaO}$ as catalyst is focused on the process optimization.

Table 2 Characteristics of products at different steam flowrate $\left(\mathrm{CaO} /\right.$ wood $=0.2$; temperature $\left.=700{ }^{\circ} \mathrm{C}\right)$

\begin{tabular}{lrrrr}
\hline Steam flowrate $(\mathrm{g} / \mathrm{h})$ & \multicolumn{1}{c}{80} & \multicolumn{1}{c}{160} & \multicolumn{1}{c}{240} & \multicolumn{1}{c}{320} \\
\hline Product distribution $(\mathrm{wt} \%)$ & & & & \\
$\quad$ Syngas & 24.80 & 29.93 & 26.35 & 22.15 \\
Tar & 7.99 & 4.90 & 5.12 & 5.17 \\
Char & 86.68 & 85.36 & 86.13 & 86.59 \\
Product characteristics & & & & \\
$\quad$ Syngas yield $\left(\mathrm{Nm}^{3} / \mathrm{kg}\right.$-wood) & 0.126 & 0.156 & 0.133 & 0.105 \\
Tar yield $\left(\mathrm{g} / \mathrm{Nm}^{3}\right)$ & 14.7 & 8.9 & 9.4 & 9.6 \\
$\mathrm{H}_{2} / \mathrm{CO}$ molar ratio & 3.41 & 5.30 & 4.24 & 3.73 \\
\hline
\end{tabular}

Considering the combined effects of catalyst loading and steam flowrate on increasing both the $\mathrm{H}_{2}$ yield and concentration, it is worth investigating if catalytic steam gasification could be served as potential approach to reduce the gasification temperature. To verify the possibility, firstly, catalytic steam gasification under different temperatures is examined.

Figure 5 gives the influences of temperature on $\mathrm{H}_{2}$ production at $\mathrm{CaO} /$ wood of 0.2 and steam flowrate of $160 \mathrm{~g} / \mathrm{h}$. The amount of $\mathrm{CaO}$ loading and steam flowrate is chosen based on the results obtained and discussed in the previous sections. It is obvious that temperature has played a crucial impact on the gasification process. The $\mathrm{H}_{2}$ concentration and yield in the syngas is significantly climbed from 0.006 $\mathrm{Nm}^{3} / \mathrm{kg}$ of wood and $18.3 \%$ at $600{ }^{\circ} \mathrm{C}$ to $0.079 \mathrm{Nm}^{3} / \mathrm{kg}$ of wood and $50.9 \%$ at $700{ }^{\circ} \mathrm{C}$, respectively. According to Le Chatelier's principle, higher temperature provides more favorable conditions for the endothermic reactions as water gas reaction (Eq. 2) and steam reforming reaction (Eq. 1), which are responsible for the accelerated $\mathrm{H}_{2}$ production and concentration output. This speculation could be evidenced by the gradually increased $\mathrm{CO}$ concentration with temperature. The enhanced tar cracking (Eq. 5) could be the second reason for the promoted $\mathrm{H}_{2}$ production at a higher temperature, which is effectively indicated by the decreasing concentration of $\mathrm{CH}_{4}$ in the syngas.

However, it is found that the $\mathrm{H}_{2}$ concentration decrease when further rises the reaction temperature from 700 to $800{ }^{\circ} \mathrm{C}$. This is accompanied by a gradual increase of $\mathrm{CO}_{2}$ concentration to $39.5 \%$ at $800{ }^{\circ} \mathrm{C}$. Previous studies have revealed that the absorption ability of $\mathrm{CaO}$ catalyst is related to the reaction temperature and $\mathrm{CO}_{2}$ equilibrium partial pressure, i.e., carbonation reaction and its reverse calcination reaction occurs under different thermodynamic limitations of the system [30-32]. Figure 6 exhibits the chemical equilibrium between $\mathrm{CO}_{2}$ equilibrium partial pressure and temperature, by the research of Baker [33]. It is proposed that for a given partial pressure of $\mathrm{CO}_{2}, \mathrm{CaO}$ carbonation takes place when the temperature is lower than the corresponding equilibrium value. But if the temperature continuously increases and exceeds the equilibrium value, carbonation reaction is inhibited and $\mathrm{CaCO}_{3}$ calcination reaction occurs. With regard to the present study, the average $\mathrm{CO}_{2}$ concentration in the reactor is around $1-2 \%$, corresponding to the $\mathrm{CaCO}_{3}$ calcination temperature of ca. 650-700 ${ }^{\circ} \mathrm{C}$. The theoretical calculation accords well with the experimental results. When the temperature reaches 750 or $800{ }^{\circ} \mathrm{C}$, the catalytic effect of $\mathrm{CaO}$ sorbent is unfavorable and little $\mathrm{CO}_{2}$ would be absorbed. As a consequence, $\mathrm{H}_{2}$ concentration drops when the temperature is higher than $700{ }^{\circ} \mathrm{C}$.

Figure 6 shows also that the $\mathrm{H}_{2}$ yield keeps rising; however, its rate of increase is declined. XRD analysis of 
Fig. 5 Effect of temperature on $\mathrm{H}_{2}$ production and syngas composition $(\mathrm{CaO} /$ wood $=0.2$; steam flowrate $=160 \mathrm{~g} / \mathrm{h}$ )

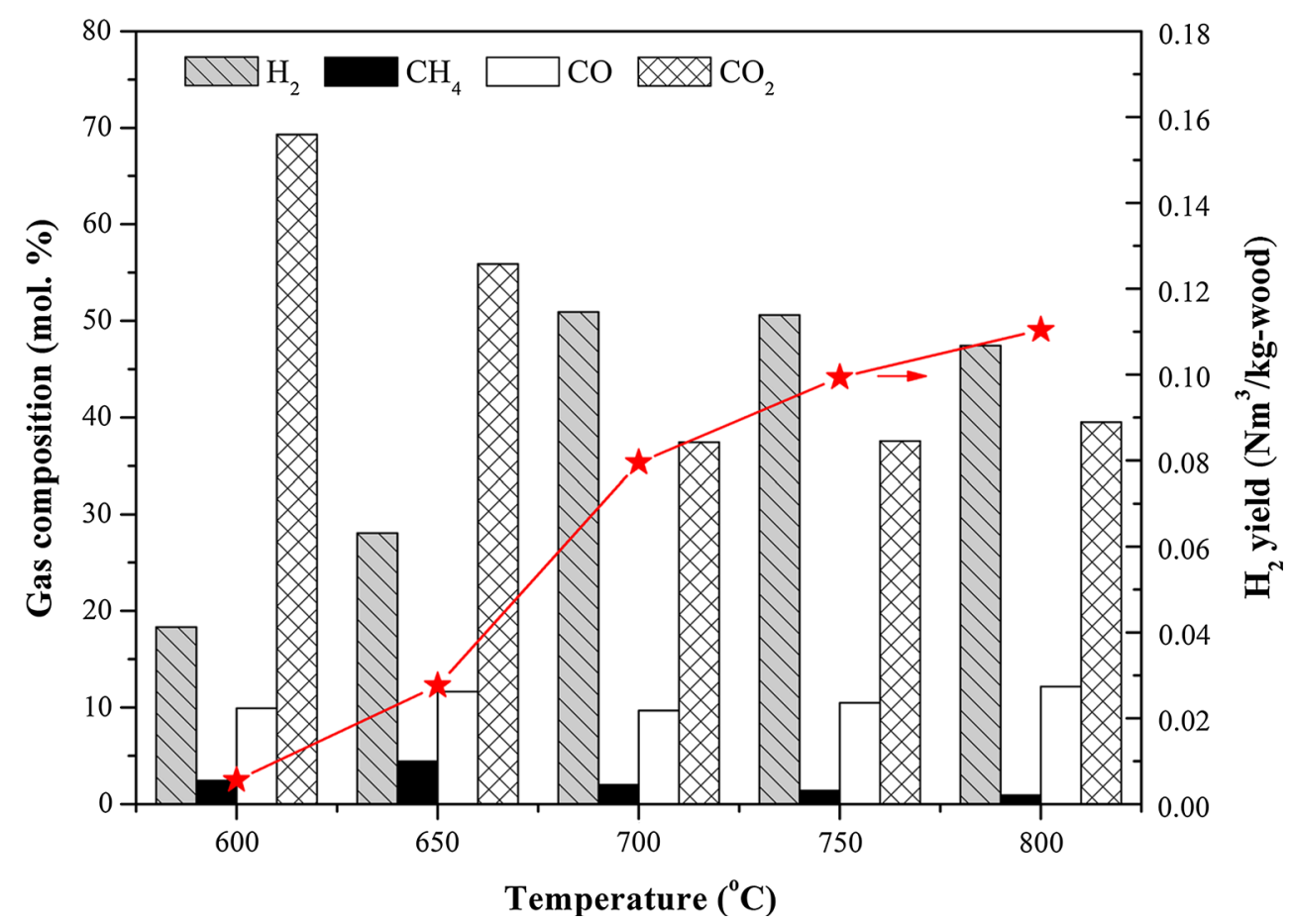

of these compounds. Literature further revealed that $\mathrm{CaO}$ obtained at high temperature is of more perfect crystal phase, and this will cause a poor catalytic activity due to fewer crystal defects [34]. As a result, it could be concluded that at temperature higher than $700{ }^{\circ} \mathrm{C}, \mathrm{CaO}$ exhibits basically the catalytic effect on tar cracking only, which leads the secondary cracking reactions into the gas fraction. However, its catalytic reactivity on $\mathrm{H}_{2}$-rich gas improvement is quite limited. Therefore, the reaction temperature should be balanced to an adequate level by considering both the $\mathrm{CO}_{2}$ absorption ability of $\mathrm{CaO}$ catalyst and the gasification performance. Besides, sintering could also be another reason for the reduced catalytic reactivity of $\mathrm{CaO}$ at higher temperature. Figure 8 gives the SEM images of $\mathrm{CaO}$ before and after reaction. It is found that the size of the particles increase, some small particles as observed in Fig. 8a disappear, or they are agglomerated into larger particles. Also, the particle surface is divided into small cracks. Since the surface area of the catalyst will decrease due to sintering, this will cause the loss of small pores necessary for the storage of the produced $\mathrm{CaCO}_{3}$ [35]. Therefore the catalytic effect of $\mathrm{CaO}$ is inferred to decrease, which seems to be severe under higher temperatures. Regarding the present data, the optimal operating temperature is $700{ }^{\circ} \mathrm{C}$ so that the formation of $\mathrm{CaCO}_{3}$ could be enhanced at the presence of $\mathrm{CaO}$ catalyst to improve the $\mathrm{H}_{2}$ production.

Then the results are further compared with non-catalyst steam gasification cases. The comparison under the same reaction temperature $\left(700{ }^{\circ} \mathrm{C}\right)$ has already been presented $800{ }^{\circ} \mathrm{C}$; on the contrary, it is converted to $\mathrm{CaO}$ or $\mathrm{Ca}(\mathrm{OH})_{2}$ under the presence of steam, resulting in quite strong peaks the solid product at $600 / 700 / 800{ }^{\circ} \mathrm{C}$ is conducted. It reveals that the catalytic activity of $\mathrm{CaO}$ is greatly affected by the eaction temperature. As shown in Fig. 7, the main peaks intensity of $\mathrm{CaCO}_{3}$ - $\mathrm{CaCO}_{3}, \mathrm{CaO}$ and $\mathrm{Ca}(\mathrm{OH})_{2}$, w diffraction peaks of $\mathrm{CaCO}_{3}$ are significantly dropped when the temperature is increased to $700{ }^{\circ} \mathrm{C}$, indicating that the decomposition of $\mathrm{CaCO}_{3}$ starts to take place and less $\mathrm{CO}_{2}$ is captured. It is also found that no $\mathrm{CaCO}_{3}$ is observed at 
Fig. 7 XRD analysis of the gasification char at different temperature $(\mathrm{CaO} /$ wood $=0.2$; steam flowrate $=160 \mathrm{~g} / \mathrm{h}$ )

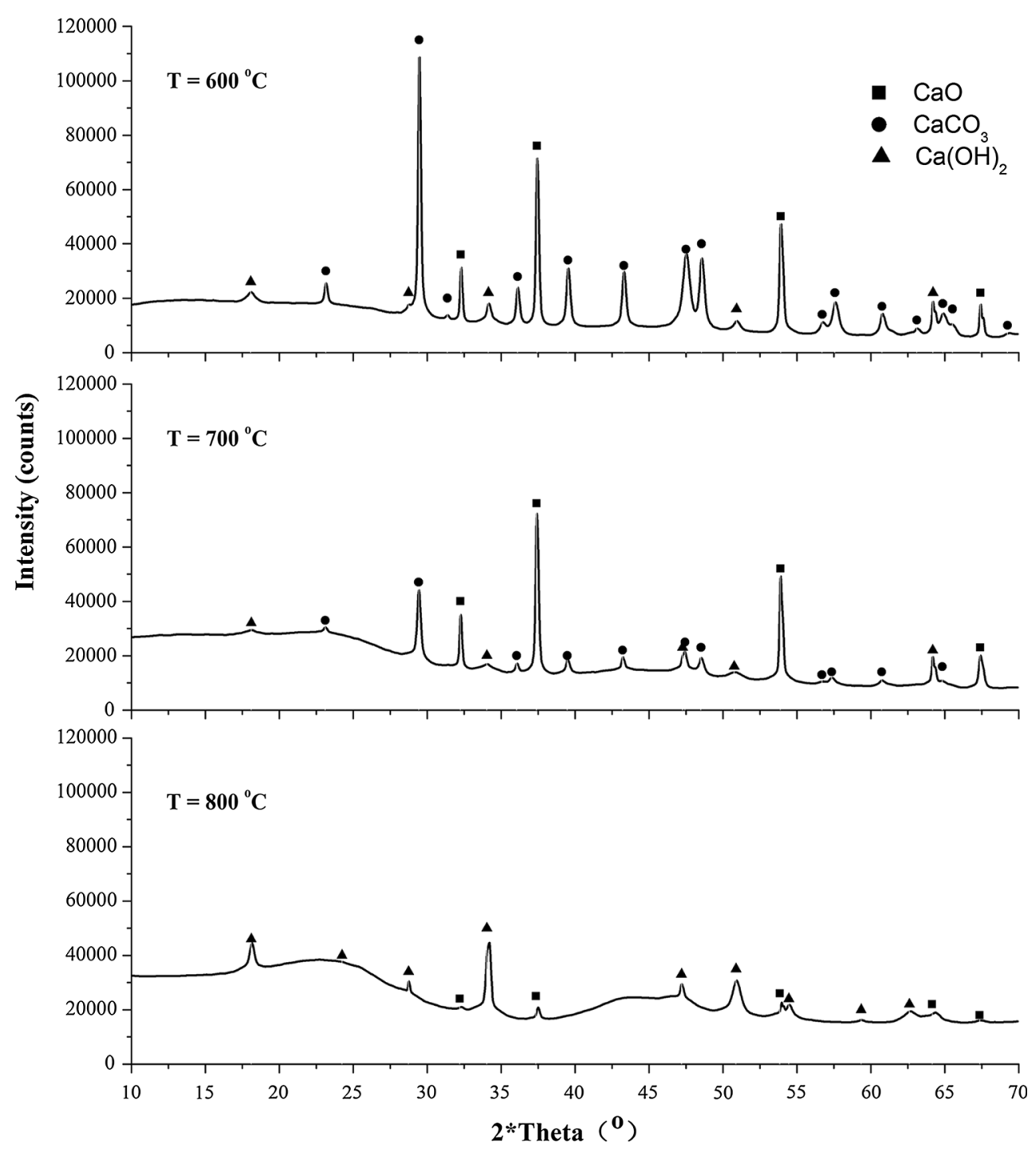

in "Catalyst Activity" section; and non-catalyst hightemperature steam gasification cases are further discussed to investigate the possibility of reducing the gasification operating temperature by using $\mathrm{CaO}$ as catalyst. Figure 9 depicts the syngas composition of both catalytic and noncatalytic steam gasification; with products characteristics illustrated in Table 3. Comparing the syngas composition, it can be seen that $20 \% \mathrm{CaO}$ addition at $700{ }^{\circ} \mathrm{C}$ could reach as high $\mathrm{H}_{2}$ content (ca. 50\%) as that gasified at $900{ }^{\circ} \mathrm{C}$ without catalyst. This value is higher than that obtained by non-catalyst gasification at $800{ }^{\circ} \mathrm{C}$; and obviously, the further increase in $\mathrm{CaO}$ addition amount will continue to raise the $\mathrm{H}_{2}$ concentration. As a result, a much higher $\mathrm{H}_{2} /$ $\mathrm{CO}$ ratio could be obtained under catalytic gasification cases, which is about 1.4-2 times higher than the cases under non-catalyst gasification (Table 3). Meanwhile, as illustrated in Table 3, the tar yield after adding the $\mathrm{CaO}$ catalyst could be declined significantly. The tar yield after
$20 \% \mathrm{CaO}$ addition at $700{ }^{\circ} \mathrm{C}$ drops to $8.9 \mathrm{~g} / \mathrm{Nm}^{3}$, which is $39 \%$ lower than the non-catalyst gasification at $900{ }^{\circ} \mathrm{C}$ $\left(14.5 \mathrm{~g} / \mathrm{Nm}^{3}\right)$, mainly attributed to the great activity of $\mathrm{CaO}$ on tar cracking.

With regard to $\mathrm{H}_{2}$ yield, $50 \% \mathrm{CaO}$ addition at $700{ }^{\circ} \mathrm{C}$ reaches $\mathrm{H}_{2}$ yield of $0.11 \mathrm{~m}^{3} / \mathrm{kg}$ of fed wood, equivalent to that gasified at $800{ }^{\circ} \mathrm{C}$ without catalyst $\left(0.10 \mathrm{~m}^{3} / \mathrm{kg}\right.$-wood $)$. By further investigating the syngas properties, it is found that the $\mathrm{H}_{2}$ concentration could be improved by $16 \%$ with $50 \%$ $\mathrm{CaO}$ addition at $700{ }^{\circ} \mathrm{C}$ compared with that under $800{ }^{\circ} \mathrm{C}$ of non-catalyst gasification. Meanwhile, $\mathrm{CO}$ and $\mathrm{CO}_{2}$ content has a marked decrease by adding $\mathrm{CaO}$ catalyst, and the $\mathrm{H}_{2}$ / $\mathrm{CO}$ ratio is thus elevated to a higher level (6.16 under 50\% $\mathrm{CaO}$ addition at $700{ }^{\circ} \mathrm{C}$ vs. 3.76 under $800{ }^{\circ} \mathrm{C}$ without catalyst). Therefore, it is concluded that using $\mathrm{CaO}$ as catalyst is an effective approach to reduce the reaction temperature of steam gasification. 50\% $\mathrm{CaO}$ addition could effectively reduce the reaction temperature by $14 \%$ (ca. $100{ }^{\circ} \mathrm{C}$ ). 

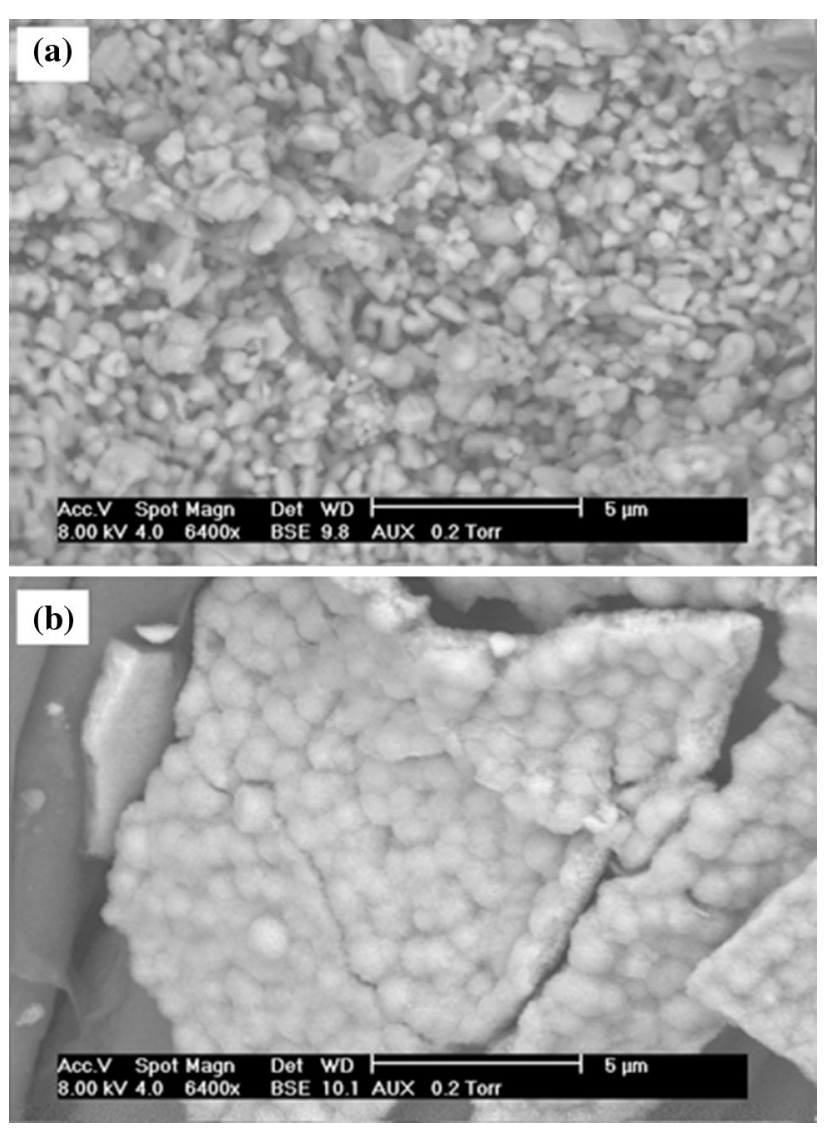

Fig. 8 SEM images of $\mathrm{CaO}$ catalyst. a Original $\mathrm{CaO}$ particles before experiment; b $\mathrm{CaO}$ particles after experiment, tested at $\mathrm{CaO} /$ wood $=1.0$, steam flowrate $=160 \mathrm{~g} / \mathrm{h}$ and temperature $=800{ }^{\circ} \mathrm{C}$

\section{Conclusions}

The catalytic steam gasification of bio-char for hydrogenrich gas production is experimentally investigated in a fluidized-bed reactor, using poplar wood as raw material and $\mathrm{CaO}$ as catalyst. The influence of operating conditions ( $\mathrm{CaO}$ activity and steam flowrate) on the $\mathrm{H}_{2}$ yield and tar reduction potential is studied. The catalytic effect of $\mathrm{CaO}$ has been examined: as $\mathrm{CO}_{2}$ acceptor, as well as to participate in the tar reforming reactions. Increasing the mass ratio of $\mathrm{CaO} /$ wood is effective for $\mathrm{H}_{2}$ improvement and simultaneously reduce the tar yield. Increasing the steam flowrate is beneficial to shift the water gas shift reactions towards $\mathrm{H}_{2}$ production. However, an excessive steam injection leads to an opposite effect, and a maximum $\mathrm{H}_{2}$ concentration and yield is achieved at steam flowrate of $160 \mathrm{~g} / \mathrm{h}$.

Based on the results obtained, process optimization is conducted to verify the potential of reducing the gasification temperature by using $\mathrm{CaO}$ as catalyst. Gasification at different temperatures reveals that the $\mathrm{H}_{2}$ concentration is decreased when temperature exceeds $700{ }^{\circ} \mathrm{C}$. $\mathrm{CaO}$ exhibits only the catalytic effect on tar cracking at higher temperature. The results are further compared with non-catalyst gasification cases. $50 \% \mathrm{CaO}$ addition at $700{ }^{\circ} \mathrm{C}$ could reach as high $\mathrm{H}_{2}$ yield as that gasified at $800{ }^{\circ} \mathrm{C}$ without catalyst. Meanwhile, a much higher $\mathrm{H}_{2}$ concentration and $\mathrm{H}_{2} / \mathrm{CO}$ ratio could be obtained under catalytic gasification cases. Therefore, it is concluded that $50 \% \mathrm{CaO}$ addition as cata-
Fig. 9 Syngas composition of catalytic and non-catalytic steam gasification. *Note: ' $700{ }^{\circ} \mathrm{C}$, non-catalyst' case stands for the same working condition as $' 700{ }^{\circ} \mathrm{C}$,

$\mathrm{CaO} / \operatorname{wood}=0$ '

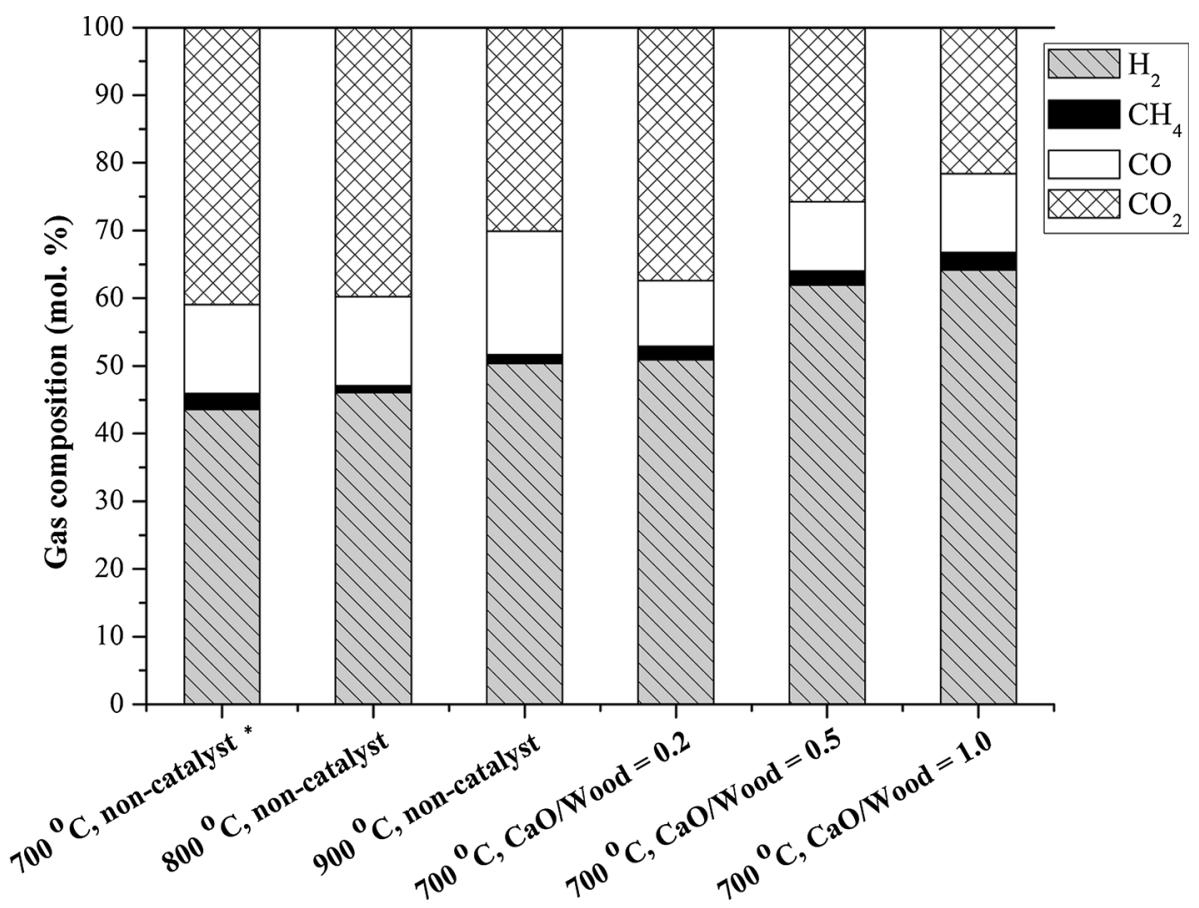


Table 3 Comparison products characteristics between catalytic and non-catalytic steam gasification

\begin{tabular}{lccclll}
\hline Condition & $\begin{array}{l}700{ }^{\circ} \mathrm{C}, \text { non- } \\
\text { catalyst }^{\mathrm{a}}\end{array}$ & $\begin{array}{l}800{ }^{\circ} \mathrm{C}, \\
\text { non-catalyst }\end{array}$ & $\begin{array}{l}900{ }^{\circ} \mathrm{C}, \\
\text { non-catalyst }\end{array}$ & $\begin{array}{l}700{ }^{\circ} \mathrm{C}, \\
\mathrm{CaO} / \text { wood }=0.2\end{array}$ & $\begin{array}{l}700{ }^{\circ} \mathrm{C}, \\
\mathrm{CaO} / \text { wood }=0.5\end{array}$ & $\begin{array}{l}700{ }^{\circ} \mathrm{C}, \\
\mathrm{CaO} / \text { wood }=1.0\end{array}$ \\
\hline $\mathrm{H}_{2}$ yield $\left(\mathrm{Nm}^{3} / \mathrm{kg}_{\text {-wood }}\right)$ & 0.06 & 0.10 & 0.16 & 0.08 & 0.11 & 0.12 \\
Tar yield $\left(\mathrm{g} / \mathrm{Nm}^{3}\right)$ & 22.4 & 20.9 & 14.5 & 8.9 & 5.5 & 3.2 \\
$\mathrm{H}_{2} / \mathrm{CO}$ & 3.36 & 3.76 & 3.02 & 5.30 & 6.16 & 5.99 \\
\hline
\end{tabular}

Catalytic steam gasification represents the working conditions under temperature $=700{ }^{\circ} \mathrm{C}$, steam flowrate $=160 \mathrm{~g} / \mathrm{h}$ while varying the $\mathrm{CaO} /$ wood mass ratios

a The case of ' $700{ }^{\circ} \mathrm{C}$, non-catalyst' stands for the same working condition as ' $700{ }^{\circ} \mathrm{C}, \mathrm{CaO} /$ wood $=0$ '

lyst at $700{ }^{\circ} \mathrm{C}$ is effective to reduce the steam gasification reaction temperature of $14 \%$ (ca. $100{ }^{\circ} \mathrm{C}$ ).

In conclusion, the results indicate that there is a strong potential for producing hydrogen-rich gas from bio-char by catalytic steam gasification with inexpensive and abundant $\mathrm{CaO}$ as catalyst. For the forthcoming research, the effect of $\mathrm{CaO}$ during raw biomass pyrolysis step should be studied, since it would catalyze pyrolysis process and the decrease in catalyst reactivity might occur. Besides, it is also worth investigating $\mathrm{CaO}$ reactivity with the aim to reduce its decay rate during gasification process. It is expected that the results could be helpful for the better utilization of biochar towards a more effective route.

Acknowledgements This project is supported by the National Natural Science Foundation of China (No. 51276168) and the Program of Introducing Talents of Discipline to University (B08026).

\section{References}

1. Zhong, C., Wei, X.: A comparative experimental study on the liquefaction of wood. Energy 29, 1731-1741 (2004)

2. Bridgwater, A., Toft, A., Brammer, J.: A techno-economic comparison of power production by biomass fast pyrolysis with gasification and combustion. Renew. Sustain. Energy Rev. 6, 181-246 (2002)

3. Scala, F., Salatino, P., Chirone, R.: Fluidized bed combustion of a biomass char (Robinia pseudoacacia). Energy Fuel 14, 781-790 (2000)

4. Tay, T., Ucar, S., Karagöz, S.: Preparation and characterization of activated carbon from waste biomass. J. Hazard. Mater. 165, 481-485 (2009)

5. Lee, J.W., Kidder, M., Evans, B.R., Paik, S., Buchanan Iii, A., Garten, C.T., Brown, R.C.: Characterization of biochars produced from cornstovers for soil amendment. Environ. Sci. Technol. 44, 7970-7974 (2010)

6. Beis, S., Onay, Ö., Koçkar, Ö.: Fixed-bed pyrolysis of safflower seed: influence of pyrolysis parameters on product yields and compositions. Renew. Energy 26, 21-32 (2002)

7. Klaas, M., Greenhalf, C., Ferrante, L., Briens, C., Berruti, F.: Optimisation of hydrogen production by steam reforming of chars derived from lumber and agricultural residues. Int. J. Hydrogen Energy 40, 3642-3647 (2015)

8. Yan, F., Luo, S.-Y., Hu, Z.-Q., Xiao, B., Cheng, G.: Hydrogenrich gas production by steam gasification of char from biomass fast pyrolysis in a fixed-bed reactor: influence of temperature and steam on hydrogen yield and syngas composition. Bioresource Technol. 101, 5633-5637 (2010)

9. Acharya, B., Dutta, A., Basu, P.: An investigation into steam gasification of biomass for hydrogen enriched gas production in presence of CaO. Int. J. Hydrogen Energy 35, 1582-1589 (2010)

10. Widyawati, M., Church, T.L., Florin, N.H., Harris, A.T.: Hydrogen synthesis from biomass pyrolysis with in situ carbon dioxide capture using calcium oxide. Int. J. Hydrogen Energy 36, 4800-4813 (2011)

11. Han, L., Wang, Q., Ma, Q., Yu, C., Luo, Z., Cen, K.: Influence of $\mathrm{CaO}$ additives on wheat-straw pyrolysis as determined by TGFTIR analysis. J. Anal. Appl. Pyrol. 88, 199-206 (2010)

12. Kuo, J.-H., Wey, M.-Y., Chen, W.-C.: Woody waste air gasification in fluidized bed with $\mathrm{Ca}$-and $\mathrm{Mg}$-modified bed materials and additives. Appl. Therm. Eng. 53, 42-48 (2013)

13. Zhou, C., Stuermer, T., Gunarathne, R., Yang, W., Blasiak, W.: Effect of calcium oxide on high-temperature steam gasification of municipal solid waste. Fuel 122, 36-46 (2014)

14. Shuai, C., Hu, S., He, L., Xiang, J., Sun, L., Su, S., Jiang, L., Chen, Q., Xu, C.: The synergistic effect of $\mathrm{Ca}(\mathrm{OH}) 2$ on the process of lignite steam gasification to produce hydrogen-rich gas. Int. J. Hydrogen Energy 39, 15506-15516 (2014)

15. Ohtsuka, Y., Asami, K.: Steam gasification of coals with calcium hydroxide. Energy Fuel 9, 1038-1042 (1995)

16. Dalai, A., Sasaoka, E., Hikita, H., Ferdous, D.: Catalytic gasification of sawdust derived from various biomass. Energy Fuel 17, 1456-1463 (2003)

17. Klinghoffer, N.: Utilization of char from biomass gasification in catalytic applications. Doctoral dissertation, Columbia University (2013)

18. Klinghoffer, N.B., Castaldi, M.J., Nzihou, A.: Catalyst properties and catalytic performance of char from biomass gasification. Ind. Eng. Chem. Res. 51, 13113-13122 (2012)

19. Kihedu, J.H., Yoshiie, R., Naruse, I.: Performance indicators for air and air-steam auto-thermal updraft gasification of biomass in packed bed reactor. Fuel Process. Technol. 141, 93-98 (2015)

20. Van Paasen, S., Kiel, J., Neeft, J., Knoef, H., Buffinga, G., Zielke, U., Sjostrom, K., Brage, C., Hasler, P., Simell, P.: Guideline for sampling and analysis of tar and particles in biomass producer gases. Final report documenting the Guideline, R\&D work and dissemination, 95 (2002)

21. Jordan, C.A., Akay, G.: Effect of $\mathrm{CaO}$ on tar production and dew point depression during gasification of fuel cane bagasse in a novel downdraft gasifier. Fuel Process. Technol. 106, 654-660 (2013)

22. Han, L., Wang, Q., Yang, Y., Yu, C., Fang, M., Luo, Z.: Hydrogen production via $\mathrm{CaO}$ sorption enhanced anaerobic gasification of sawdust in a bubbling fluidized bed. Int. J. Hydrogen Energy 36, 4820-4829 (2011)

23. Udomsirichakorn, J., Basu, P., Salam, P.A., Acharya, B.: Effect of $\mathrm{CaO}$ on tar reforming to hydrogen-enriched gas with in- 
process $\mathrm{CO}_{2}$ capture in a bubbling fluidized bed biomass steam gasifier. Int. J. Hydrogen Energy 38, 14495-14504 (2013)

24. Arena, U.: Process and technological aspects of municipal solid waste gasification. A review. Waste Manage. 32, 625-639 (2012)

25. Manovic, V., Lu, D., Anthony, E.J.: Steam hydration of sorbents from a dual fluidized bed $\mathrm{CO}_{2}$ looping cycle reactor. Fuel 87, 3344-3352 (2008)

26. Li, J., Liao, S., Dan, W., Jia, K., Zhou, X.: Experimental study on catalytic steam gasification of municipal solid waste for bioenergy production in a combined fixed bed reactor. Biomass Bioenergy 46, 174-180 (2012)

27. Paviet, F., Bals, O., Antonini, G.: The effects of diffusional resistance on wood char gasification. Process Saf. Environ. 86, 131-140 (2008)

28. He, M., Xiao, B., Liu, S., Guo, X., Luo, S., Xu, Z., Feng, Y., Hu, $Z$ : Hydrogen-rich gas from catalytic steam gasification of municipal solid waste (MSW): influence of steam to MSW ratios and weight hourly space velocity on gas production and composition. Int. J. Hydrogen Energy 34, 2174-2183 (2009)

29. De Filippis, P., Borgianni, C., Paolucci, M., Pochetti, F.: Prediction of syngas quality for two-stage gasification of selected waste feedstocks. Waste Manag. 24, 633-639 (2004)
30. Florin, N.H., Harris, A.T.: Enhanced hydrogen production from biomass with in situ carbon dioxide capture using calcium oxide sorbents. Chem. Eng. Sci. 63, 287-316 (2008)

31. Florin, N.H., Harris, A.T.: Hydrogen production from biomass coupled with carbon dioxide capture: the implications of thermodynamic equilibrium. Int. J. Hydrogen Energy 32, 4119-4134 (2007)

32. Blamey, J., Anthony, E., Wang, J., Fennell, P.: The calcium looping cycle for large-scale $\mathrm{CO}_{2}$ capture. Prog. Energ. Combust. 36, 260-279 (2010)

33. Baker, E.: The calcium oxide-carbon dioxide system in the pressure range 1-300 atmospheres. J. Chem. Soc., 464-470 (1962)

34. Feng, B., Bhatia, S.K., Barry, J.C.: Variation of the crystalline structure of coal char during gasification. Energ. Fuel. 17, 744-754 (2003)

35. Grasa, G.S., Abanades, J.C.: $\mathrm{CO}_{2}$ capture capacity of $\mathrm{CaO}$ in long series of carbonation/calcination cycles. Ind. Eng. Chem. Res. 45, 8846-8851 (2006) 